PHYSICAL REVIEW X 2, 039903 (2012)

\title{
Publisher's Note: Ultrasensitive and Wide-Bandwidth Thermal Measurements of Graphene at Low Temperatures \\ [Phys. Rev. X 2, 031006 (2012)]
}

Kin Chung Fong and K. C. Schwab

(Received 2 August 2012; published 6 August 2012)

DOI: 10.1103/PhysRevX.2.039903

Subject Areas: Graphene, Mesoscopics, Photonics

This paper was published online on 30 July 2012 with an omission of an author byline footnote. Kin Chung Fong's byline footnote should read as "kcfong@ caltech.edu". The byline footnote has been added online as of 03 August 2012.

Published by the American Physical Society under the terms of the Creative Commons Attribution 3.0 License. Further distribution of this work must maintain attribution to the author(s) and the published article's title, journal citation, and DOI. 